
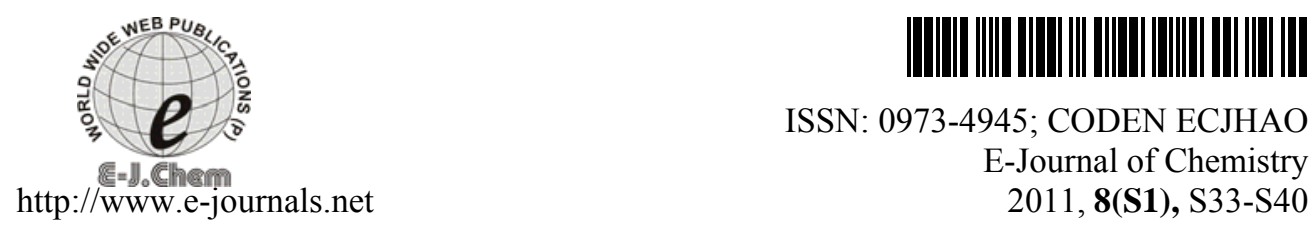

ISSN: 0973-4945; CODEN ECJHAO

E-Journal of Chemistry

2011, 8(S1), S33-S40

\title{
The Effects of Various Acid Catalyst on the Esterification of Jatropha Curcas Oil based Trimethylolpropane Ester as Biolubricant Base Stock
}

\author{
NOOR HAFIZAH ARBAIN and JUMAT SALIMON*
}

School of Chemical Sciences and Food Technology

Faculty of Science and Technology, Universiti Kebangsaan Malaysia

43600 UKM Bangi, Selangor Darul Ehsan, Malaysia

jumat@ukm.my

Received 21 January 2011; Accepted 12 April 2011

\begin{abstract}
Biolubricant production of trimethylolpropane ester (ET) was conducted via esterification of fatty acid (FA) of Jatropha curcas oil with trimethylolpropane (TMP). The condition for this reaction was as follows: temperature was $150{ }^{\circ} \mathrm{C}$, time of reaction was 3 hours, molar ratio of FA: TMP was $4: 1$ and $2 \% \mathrm{wt} / \mathrm{wt}$ concentrated catalyst (based on weight of FA). Different catalyst was used in this reaction such as perchloric acid, sulfuric acid, $p$-toluenesulfonic acid, hydrochloric acid, and nitric acid. The composition of ET was determined by Gas Chromatography (GC-FID). The ester group was confirmed by Fourier Transform Infrared Spectroscopy (FTIR) and the structure was confirmed by proton and carbon Nuclear Magnetic Resonance $\left({ }^{1} \mathrm{H}-\mathrm{NMR}\right.$ and ${ }^{13} \mathrm{C}$-NMR) spectra. $70 \%$ of ET was successfully synthesized using perchloric acid in this research. The pour point of the product was observed as low as $-23^{\circ} \mathrm{C}$, flash point is $>300{ }^{\circ} \mathrm{C}$ and viscosity index is 150 .
\end{abstract}

Keywords: Jatropha curcas, Biolubricant, Jatropha oil fatty acid, Esterification, Trimethylolpropane ester

\section{Introduction}

Increase awareness among the community of environmental pollution by petroleum-based oils for use as industrial lubricants cause the switch to vegetable oil which is more environmental friendly. The searching for using alternative sources in the preparation of lubricants has begun to actively investigate. Bioubricant production using vegetable oil gives the various advantages that is the source of renewable, cheap, biodegradated and no adverse effects on nature ${ }^{1}$. The problems faced by vegetable oil are that it has low thermal and oxidative stability due to the existing double bond ${ }^{2}$ and the presence of active sites in the $\beta$ hydrogen of triacylgliserol ester. To overcome this problem, modifications to the study carried out on crude oil to produce better quality of biolubricant which has better oxidative stability and pour point. 
In this study, Jatropha curcas oil (JCO) is used as the source for the biolubricant production. Jatropha curcas is a species of the family Euphorbiaceae which is widely grown in South America, South-West Asia, India and Africa. This species has a high resistance to hot and dry climate. It can grow in many places, even in arid or sandy soil. Oil from Jatropha seeds gives valuable products with features that have low acidity, high oxidative stability compared to soybean oil, low viscosity compared with castor oil and better cooling characteristics of palm oil. Fatty acids content in crude oil are $42-44 \%$ oleic acid, linoleic acid 33-34\% and 6-7\% saturated fatty acids ${ }^{3}$. The observed major triacylglycerol (TAG) composition was PLL $(20.40 \%)$ and OOL $(17.98 \%)^{4}$. The oil was used as a diesel substitute during the World War II. JCO is available locally and it is nonedible vegetable oil due to its high toxicity. The utilisation of non-edible and renewable crops such as Jatropha in biofuels production is crucial to minimize the utilisation of edible food crops (corn, soya, etc.) as it is expected to create a short supply of food for human consumption. In addition, increasing environmental awareness and diminishing petroleum resources leads research on alternative non edible crops for biofuel production ${ }^{5}$.

However, due to the presence of hydrogen in the structure of glycerol- $\beta$ of the oil which is causing the oil has low thermal and oxidative stability, fatty acid of Jatropha curcas oil will be reacted with a polyol such as trimethylolpropane (TMP) to produce TMP ester. TMP polyol is selected because of the branching structure and has a low melting point. Polyol esters are excellent substitutes for mineral oils because of their low volatility, high flash point, good thermal stability, low toxicity and excellent biodegradability ${ }^{6}$. Chemical modification such as transesterification of vegetable oils with polyols has shown increased levels of oxidative stability of vegetable oil-based lubricants ${ }^{7}$. Among the methods that can be used to improve the properties of vegetable oil as biolubricant is to change the structure of the oil to polyol ester of the branched polyol. The absence of a hydrogen atom at carbon- $\beta$ in the structure of the ester oil is made with high thermal and oxidative stability ${ }^{8}$. The scheme of esterification of fatty acid (FA) of Jatropha curcas oil with TMP is shown in Figure 1.

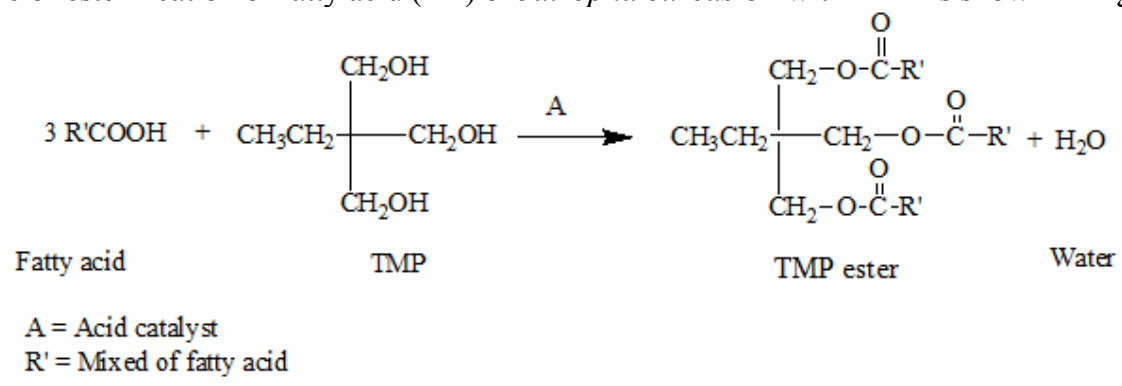

Figure 1. Esterification of fatty acid (FA) of Jatropha curcas oil with trimethylolpropane (TMP)

Esterification reactions are normally catalysed by acidic or basic based catalysts. The most common acid catalysts are $p$-toluenesulphonic acid, phosphoric acid, sulphuric acid, sodium hydroxide, sodium ethoxide and sodium methoxide ${ }^{9}$. Using basic homogenous catalyst would result in high amounts of saop formation in the reaction. This is due to this feedstock has a high amount of free fatty acid (FFA) which is much higher than the maximum amount suitable to be used with basic homogeneous catalysts. Therefore, alternative ways should be employed, to avoid this reaction, for example with a homogeneous acid catalyst, solid resins, or enzymes ${ }^{10}$. For enzyme catalyst's, the features of the substrates selected influence the properties of the ester manufactured. 
Previous study has been reported that ester production was carried out by esterification reaction of TMP with isovaleric acid and $n$-valerik. $85 \%$ of the esters produced by using $7 \%$ sodium bisulphate catalyst at a temperature of $110-120{ }^{\circ} \mathrm{C}$ for 2 hours. The use of $1 \%$ sulfuric acid catalyst in the same reaction resulted in $78 \%$ ester at a temperature of $110-120{ }^{\circ} \mathrm{C}$ for 60 hours $^{11}$. There are also the studies of TMP ester production carried out by transesterification reaction of palm oil methyl ester (POME) with trimetilolpropana (TMP) or palm kernel oil methyl esters (PKOME) with the yield of $98 \%$ triester (TE) ${ }^{12}$. Transesterification reaction is carried out at a temperature of $130{ }^{\circ} \mathrm{C}$ under a pressure of 20 mbar for 1 hour with the addition of $0.8 \%$ sodium methoxide catalyst ${ }^{13}$. Another study showed a $99 \%$ triester resulting from esterification reaction of rapeseed oil methyl ester with TMP. The reaction was carried out at temperature $110-120{ }^{\circ} \mathrm{C}$ for 10 hours under the pressure of $3.3 \mathrm{kPa}$ with the addition of $0.5 \%$ catalyst sodium methylate ${ }^{14}$. In this paper, we report the effects of various acid catalyst on the esterification of Jatropha curcas oil based trimethylolpropane ester as biolubricant base stock.

\section{Experimental}

Jatropha curcas were obtained from House Plant in National University of Malaysia. Fatty acid was prepared according to modified PORIM Test Method ${ }^{15}$. TMP was purchased from Fluka, perchloric acid, sulfuric acid, $p$-toluenesulfonic acid, hydrochloric acid nitric acid, ethyl acetate, sodium bicarbonate and sodium chloride was purchased from Systerm, and toluene was purchased from Merck. Samples were confirmed by FTIR (Figure 2), ${ }^{1} \mathrm{H}$ and ${ }^{13} \mathrm{C}$ NMR spectra (Figure 3 and Figure 4) and analysed at certain time intervals for fatty acid (FA), monoesters (ME), diesters (DE) and triesters (TE) by gas chromatography (Figure 5). The GC equipped with Flame Ionization Detector (FID) system was performed using the capillary column DB-5HT, $30 \mathrm{~m} \times 0.25 \mathrm{~mm}$, i.d. $0.10 \mu \mathrm{m}$ (DB, United States). The oven temperature was set initially at $100{ }^{\circ} \mathrm{C}$, held for $1 \mathrm{~min}$, then increased at $5{ }^{\circ} \mathrm{C} / \mathrm{min}$ to $380^{\circ} \mathrm{C}$ and held for another $25 \mathrm{~min}$. The injector and detector temperatures were at $380{ }^{\circ} \mathrm{C}$.

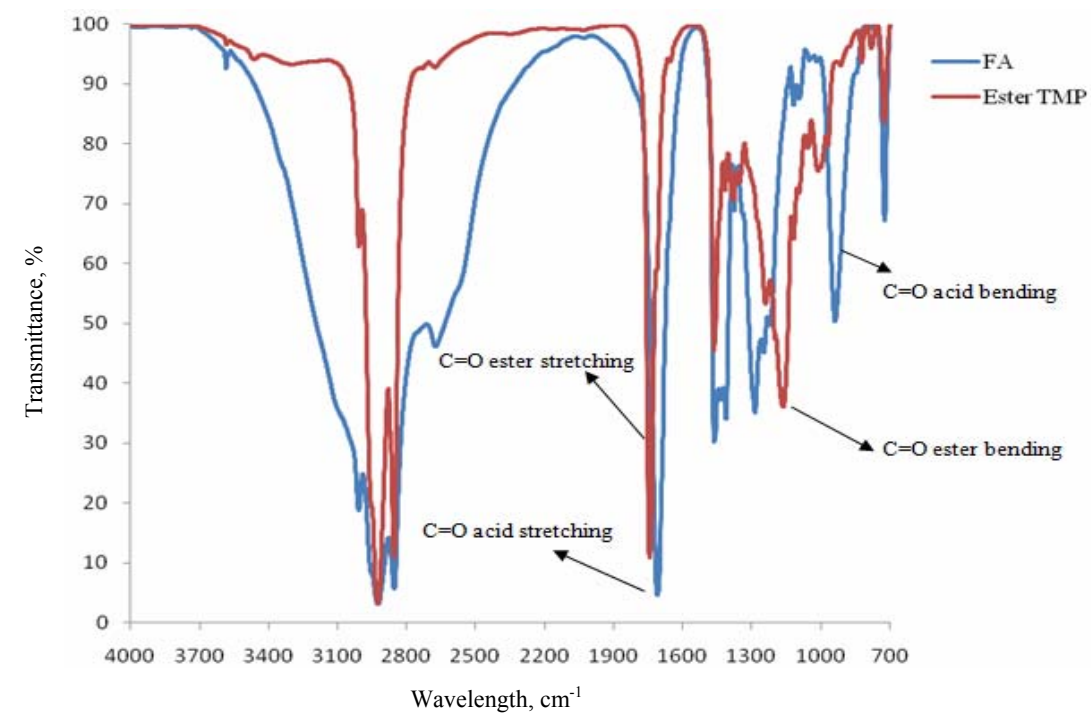

Figure 2. The comparison between the IR spectra of Jatropha curcas oil fatty acid and Jatropha curcas oil based TMP ester 


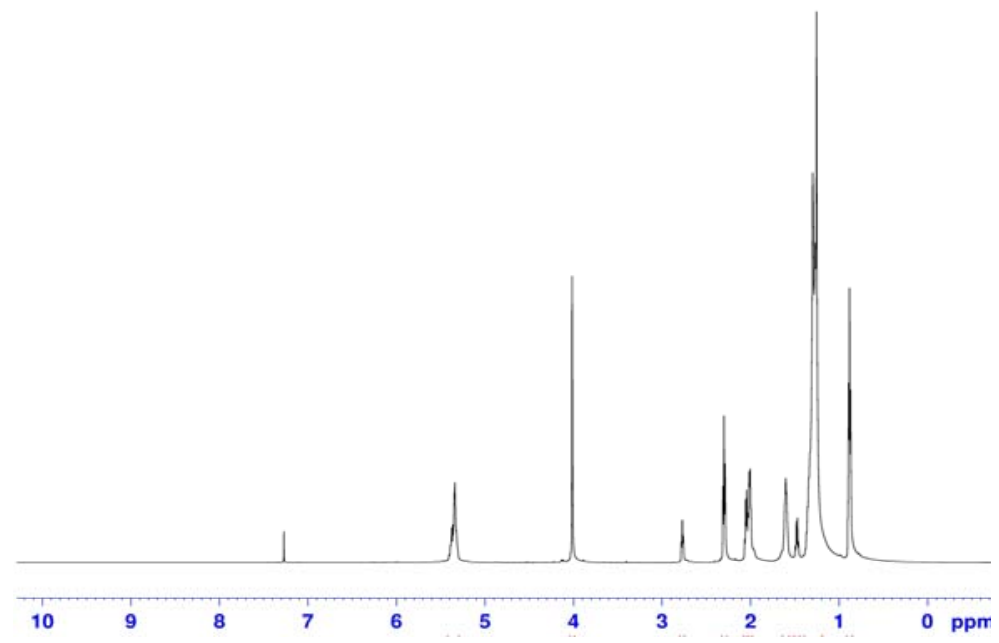

Figure 3. The ${ }^{1} \mathrm{H}$ NMR spectra of Jatropha curcas oil based TMP ester

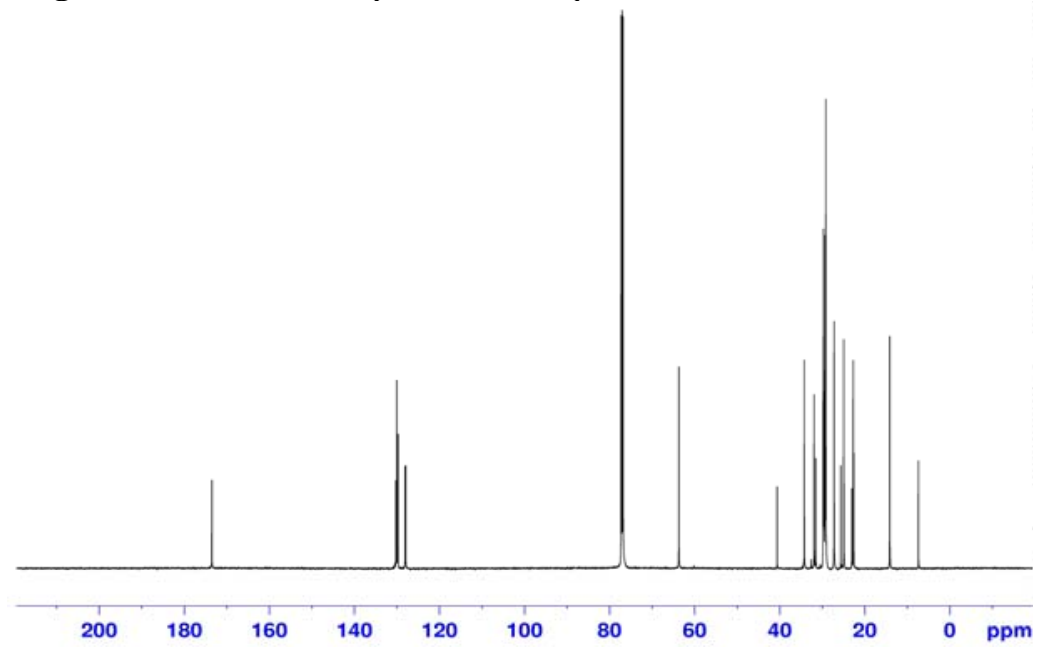

Figure 4. The ${ }^{13} \mathrm{C}$ NMR spectra of Jatropha curcas oil based TMP ester

A two stage process was used in the preparation of acid of Jatropha curcas oil. The first step was saponification with alkaline- ethanol solution that were refluxed for two hours. Then, the next step was hydrolysis. The hidrolysis reaction involves the uses of water and acidic solution to neutralized the alkaline solution. The solvent was then removed using rotary evaporator under reduced pressure at temperature of $70{ }^{\circ} \mathrm{C}$. The sample was determined from the FTIR spectroscopy.

The esterification reaction in this study was refer according to Itsikson et al. $1967^{11}$. The reaction was performed in a three necked round bottom flask equipped with a Dean and Stark water separator. Twenty gram of fatty acid, known amount of TMP and toluene were placed in the flask under constant stirring provided by the magnetic stirrer. The weight of TMP was determined based on the required molar ratio of the fatty acid. The toluene used as azeotroping agent in this reaction. The temperature was raised to the boiling point of the reaction mixture after which the catalyst was added. The condition for this reaction was as 
follows: temperature was $150{ }^{\circ} \mathrm{C}$, time of reaction was 3 hours, molar ratio of FA:TMP was $4: 1$ and $2 \% \mathrm{wt} / \mathrm{wt}$ catalyst (based on weight of FA). Different catalyst was used in this reaction such as perchloric acid, sulfuric acid, $p$-toluenesulfonic acid, hydrochloric acid and nitric acid. When the reaction was complete, the solution washed and neutralized using water and alkaline solution to remove catalyst. The solvent removed using a rotary evaporator under reduced pressure at $80^{\circ} \mathrm{C}$.

For the lubrication characteristics, the pour point, flash point, viscosity index, viscosity at $40^{\circ} \mathrm{C}$ and $100{ }^{\circ} \mathrm{C}$ of the TMP ester were measured according to ASTM D 97, ASTM D 92 ASTM D 2270 and ASTM D 445 (Rheometer Model Anton Paar. A spindle of CP25-2 used at $40{ }^{\circ} \mathrm{C}$ and $100{ }^{\circ} \mathrm{C}$ at room temperature $)^{16}$.

\section{Results and Discussion}

The presence of ester group of TMP ester is determined by the infrared spectrum (FTIR). The comparison between the FTIR spectrums of fatty acid after hydrolysis with the spectrum of TMP ester after esterification is shown in Figure 2. Based on the comparison of the spectrum of FA with ET, the wavelength of the presence of alcohol, $-\mathrm{OH}\left(3300-3100 \mathrm{~cm}^{-1}\right)$ does not look directly at the spectrum of TMP ester. This indicates that the OH bond in TMP react fully with the fatty acids to form TMP ester.

In addition, there is a shift in the wavelength of $1711 \mathrm{~cm}^{-1}$ for the spectrum of fatty acids to the wavelength of $1743 \mathrm{~cm}^{-1}$ for the spectrum of TMP ester. The value of $1711 \mathrm{~cm}^{-1}$ is carboxylic acid functional groups and after the process of esterification, ester formation produced at the wavelength $1743 \mathrm{~cm}^{-1}$. There is also a wavelength that appears after the esterification is at $1056 \mathrm{~cm}^{-1}$ which is shows the functional group of the $\mathrm{CO}$ bond as the result of the formation of TMP ester ${ }^{17}$.

The use of NMR methods is very important for determining the molecular structure of a chemical. The result of merging data from infrared spectroscopy (to determine the function of a compound) and NMR (provides information on the number of each type of hydrogen) is sufficient to determine more about an unknown structure ${ }^{18}$.

The resulting spectrum of ${ }^{1} \mathrm{H}$ NMR analysis that provides some important guidance in determining the structure for the TMP ester has been produced (Table 1). The results of the analysis found that the existence of signals of methylene protons bound to $-\mathrm{O}$ of the ester group,-OOR that is the major methyl ester of TMP in the study. Signals at $4.004 \mathrm{ppm}$ are for the methylene protons at the (methylene) carbon are formed in TMP ester. Based on information from the software Chemdraw and the reference ${ }^{17}$, the value is respectively $4.00 \mathrm{ppm}$. Thus, the existence of the signal is then established that the ester product is TMP ester. Besides, proton signals at 5.3-5.4 ppm is appeared which is refer to the proton of $\mathrm{C}=\mathrm{C}-\mathrm{H}$ proton of olefin that the values are also present in the analysis Chemdraw and the reference ${ }^{17}$.

Table 1. ${ }^{1} \mathrm{H}-\mathrm{NMR}$ data for Jatropha curcas oil based TMP ester.

\begin{tabular}{cccc}
\hline Compound & $\begin{array}{c}\text { Chemicals shifts, } \\
\text { ppm }\end{array}$ & $\begin{array}{c}\text { Chemical shift, ppm } \\
\text { (Theoretical, Pavia et al. 2009) }\end{array}$ & Conclusion \\
\hline \multirow{2}{*}{ ET } & 4.004 & 4.0 & RCO-O-C-H (Ester) \\
& $5.301,5.356,5.374$ & $5.3-5.4$ & C=C-H \\
\hline
\end{tabular}

${ }^{13} \mathrm{C}$ NMR spectrum also plays an important role in displaying the important features of TMP ester produced (Table 2). Ester carbonyl signals in the range of 173-174 ppm are very important in this study. The signal at the range is representing the functional group ester carbonyl at the end of the esterification of TMP. 
In this study of polyol ester, ester carbonyl signals appear in the range of $173.5 \mathrm{ppm}$. According to the software Chemdraw, ester carbon signal is present at about $172 \mathrm{ppm}$. Based on the ${ }^{13} \mathrm{C}$ NMR spectrum, there is also a clear signal at $77.25 \mathrm{ppm}$, which refers to the chloroform signal, $\mathrm{CDCl}_{3}$. After successfully interpreting NMR data, the result of the expected TMP ester obtained are shown in Table 1 and Table 2.

Table 2. ${ }^{13} \mathrm{C}-\mathrm{NMR}$ data for Jatropha curcas oil based TMP ester

\begin{tabular}{cccc}
\hline Compound & Chemicals shifts, ppm & $\begin{array}{c}\text { Chemical shift, ppm } \\
\text { (Theoretical, Pavia } \text { et al. 2009) }\end{array}$ & Conclusion \\
\hline ET & 173.5 & $155-185$ & $\mathrm{C}=\mathrm{O}$ ester \\
\hline
\end{tabular}

GC chromatogram of TMP ester is shown in Figure 5. The peaks appeared was identified and labeled based on the number of alkyl carbon groups that attached to TMP backbone. The esters formed are identified by making comparisons by standard or by using the standard of triglyceride (TG), diglycerides (DG) and monogliceride $(\mathrm{MG})^{19}$. The composition of products containing $0.8 \%$ fatty acid (FA), $1.13 \%$ diester (DE) and $98.1 \%$ of triester (TE) (Table 3 ).

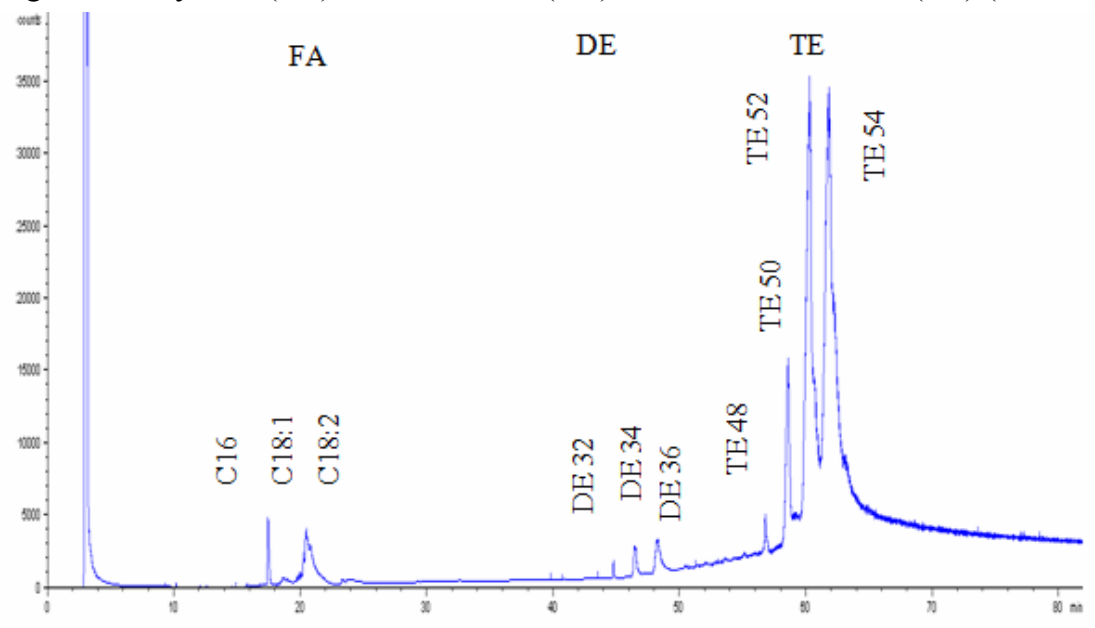

Figure 5. GC chromatogram of Jatropha curcas oil based TMP ester.

Table 3. Composition of products of esterification of TMP ester

\begin{tabular}{cc}
\hline Products & Percentage, $\%$ \\
\hline Fatty acid & 0.8 \\
Monoester & - \\
Diester & 1.13 \\
Triester & 98.1 \\
\hline
\end{tabular}

The catalyst is an important factor in esterification of TMP ester. Perchloric acid, sulfuric acid, $p$-toluenesulfonic acid, hydrochloric acid and nitric acid were used in this study because they are strong acids. These catalyst is neutralized at the end of the reaction to separate the product. From Table 4, it was found that perchloric acid gives higher \% yield of TMP ester compared to sulfuric acid, $p$-toluenesulfonic acid, hydrochloric acid and nitric acid. It gives $70 \%$ of ET, while sulfuric acid gives $46 \%$ yield of ET, $p$-toluenesulfonic acid gives $42 \%$ yield of ET, hydrochloric acid gives $41 \%$ yield of ET and nitric acid gives $37 \%$ yield of ET. Perchloric acid is the inorganic compound with the formula $\mathrm{HClO}_{4}$ is a strong acid in strength comparable to sulfuric and nitric acids which is one of the strongest Brønsted-Lowry 
acids. It's $\mathrm{pKa}$ is $-10^{20}$. It provides strong acidity without interference from potential nucleophiles such as sulfate or chloride that complicate the use of sulfuric and hydrochloric acids. This acid are not susceptible to hydrolysis, whereas it's favor the forward reaction of the esterification, thus increasing the yield of ET in this study. Therefore, perchloric acid are suitable reagent for esterification of TMP ester to increase biolubricant production of the reaction.

Table 4. \% yield of TMP ester based on catalyst used

\begin{tabular}{ccc}
\hline Catalyst & Amount of catalyst, \%wt/wt & ${ }^{*}$ Yield, \% \\
\hline Perchloric acid & 2 & 70 \\
Sulfuric acid & 2 & 46 \\
$p$-toluenesulfonic acid & 2 & 42 \\
Hydrochloric acid & 2 & 41 \\
Nitric acid & 2 & 37 \\
\hline
\end{tabular}

Reaction conditions- temperature: $150{ }^{\circ} \mathrm{C}$, time: 3 hours, molar ratio of FA: TMP: $4: 1$ and $2 \% \mathrm{wt} / \mathrm{wt}$ catalyst (based on weight of FA). "The \% yield is based on the weight of the product (\% wt/wt)

For the characterization of biolubricant base stocks, the uses of branched chain are improving low temperature properties and hydrolytic stability. The higher degree of branching chain gives good low-temperature properties, high hydrolytic stability and high viscosity index ${ }^{21}$. Based on Table 5 , the resulting viscosity of TMP ester at $40{ }^{\circ} \mathrm{C}$ and $100{ }^{\circ} \mathrm{C}$ are $63.1 \mathrm{cSt}$ and $12.1 \mathrm{cSt}$ respectively. Biolubricant produced from this study have a larger molecular chain and branched. Therefore, it has a higher molecular mass compared to the original structure of JCO. This resulted in viscosity values were also higher than the oil.

Table 5. Characterization of JCO, FA and TMP ester as biolubricant base stock

\begin{tabular}{ccc}
\hline Characterization & JCO & TMP Ester \\
\hline Pour point, ${ }^{\circ} \mathrm{C}$ & 10 & -23 \\
Flash point, ${ }^{\circ} \mathrm{C}$ & 200 & $>300$ \\
Viscosity at $40{ }^{\circ} \mathrm{C}(\mathrm{cSt})$ & 36.4 & 63.1 \\
Viscosity at $100{ }^{\circ} \mathrm{C}(\mathrm{cSt})$ & 8.7 & 12.1 \\
Viscosity Index & 164 & 150
\end{tabular}

Pour point of TMP ester obtained in this study is $-23{ }^{\circ} \mathrm{C}$. Formation of a complex chain and branched oils will have a lower pour point ${ }^{22}$. At low temperature, oil composition capable of forming macrocistal for a uniform chain. The existence of branches in the fatty acid chains is able to retard the process of composition. This is because the presence of branches was able to create barriers around the congestion of each molecule and prevent crystallization. Therefore, it will lower the pour point ${ }^{21}$.

The results of the analysis found that the flash point of TMP ester produced was $>300{ }^{\circ} \mathrm{C}$ which is greater than origin oil. Flash point is influenced by the number of carbon contained in the structure. The more the number of carbon, the higher the flash point. The high values of flash point indicate that the resulting TMP ester has a high potential for the production of lubricants.

\section{Conclusion}

In this study, TMP ester was successfully synthesized in this research using fatty acid of Jatropha curcas oil with trimethylolpropane in the presence of perchloric acid as catalyst with $70 \%$ yields of product. The results obtain suggested that the following reaction time: 3 
hours, temperature: $150{ }^{\circ} \mathrm{C}$, molar ratio of FA: TMP is $4: 1$ and amount of catalyst: $2 \% \mathrm{wt} / \mathrm{wt}$ (based on weight of FA) using perchloric acid are sufficient for the esterification of TMP ester as biolubricant base stock. In addition, the pour point of the product was observed as low as $23{ }^{\circ} \mathrm{C}$, flash point is $>300{ }^{\circ} \mathrm{C}$ and viscosity at $40{ }^{\circ} \mathrm{C}$ and $100{ }^{\circ} \mathrm{C}$ are $63.1 \mathrm{cSt}$ and $12.1 \mathrm{cSt}$ respectively that resulting TMP ester has a high potential for the production of lubricants.

\section{Acknowledgment}

The authors would like to thanks to the School of Chemical Sciences and Food Technology, Faculty of Science and Technology and Universiti Kebangsaan Malaysia for the financial support via research grant no. (UKM-OUP-NBT-28-145/2009).

\section{References}

1. $\quad$ Asadauskas S and Erhan S Z,. J Am Oil Chem Soc., 1999, 76(3), 313-316.

2. Lathi S P and Mattiason B, J Appl Catal B: Environ., 2006,.69, 207-212.

3. Tapanes N C O, Aranda D A G, Carneiro J W M and Antunes O A C, Fuel., 2008, 87, 2286- 2295.

4. $\quad$ Salimon J and Rozaini A, Sains Malaysiana, 2008, 37(4), 379-382.

5. Emil A, Zahira Y, Satheesh Kumar M N, Jahim J M and Salimon J, J Am Oil Chem Soc., 2010, 87, 689-695.

6. Hwang H S, Adhvaryu, Atanu and Erhan S Z, J Am Oil Chem Soc., 2003, 80, 811 815.

7. Wu X, Zhang X S, Yang H C and Wang D, J Amer Oil Chem Soc., 1998, 75, 1557-1563.

8. Wilson B, Ind Lubr Tribol., 1998, 50(1), 6-15.

9. Kleinová A, Fodran P, Brnčalová P and Cvengroš C, Biomass Bioenergy, 2008, 32, 366-371.

10. Marchetti J M and Errazu A F, Biomass Bioenergy, 2008, 32(9), 892 - 895.

11. Itsikson T M, Milovidova N V and Rapport I B, Khimiya i Teknologiya Topliv i Masel, 1967, 6, 14-16.

12. Robiah Y, Fakhru'l-Razi A, Ooi T L, Iyuke S E and dan Idris A, J Oil Palm Res., 2003a, 15(2), 35-41.

13. Robiah Y, Fakhru'l-Razi A, Ooi T L, Iyuke S E and dan Idris A, J Oil Palm Res., 2003b, 15(2), 42-49.

14. Uosukainen E, Linko Y Y, Lamsa M, Tervakangas T and dan Linko P, J Am Oil Chem Soc., 1998, 75(11), 1557-1563.

15. PORIM Test Method. Bandar Baru Bangi: Palm Oil Research Institute of Malaysia, 1995

16. ASTM, Annual Book of ASTM Standards, Petroleum Products, Lubricants and Fossil Fuels. $5^{\text {th }}$ Ed., American Society for Testing and Materials, Philadephia. 1995, 57-59, 154-159.

17. Pavia D.L, Lampman G M and Kriz G.S, Introduction to Spectroscopy. $4^{\text {th }}$ Ed., United States: Thomson Learning, Inc., 2009

18. Pavia D L, Lampman G M and Kriz G S, Introduction to Spectroscopy. $3^{\text {rd }}$ Ed., United States: Thomson Learning, Inc., 2001

19. Robiah Y, Ooi T L, Fakhru'l-Razi A and Shahnor B, J Am Oil Chem Soc., 2002, 79, 1075-1080.

20. Kathleen S, Katherine W, William R A, Stephen R C, Marilyn H and Barbara P, Perchlorate: Environmental Problems and Solutions, CRC Press. 2006, 16.

21. Sharma B K, Doll K M and Erhan S Z, Bioresources Technol., 2008, 99, 7333-7340.

22. Cermak S C and Isbell T A, Ind Crops Prod, 2003, 18, 183-196. 


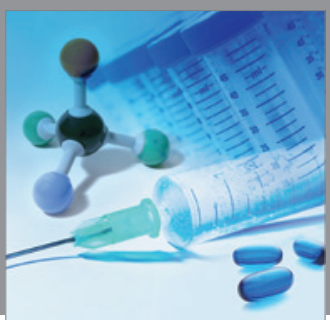

International Journal of

Medicinal Chemistry

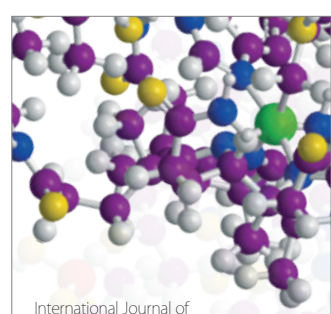

Carbohydrate Chemistry

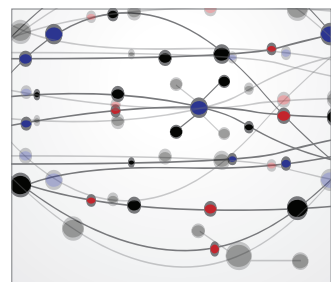

The Scientific World Journal
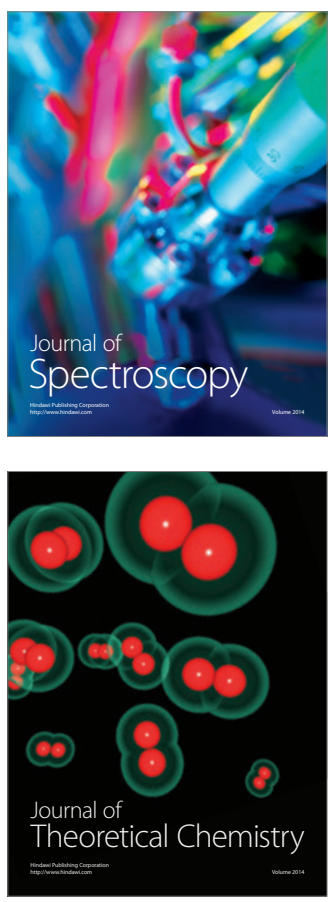
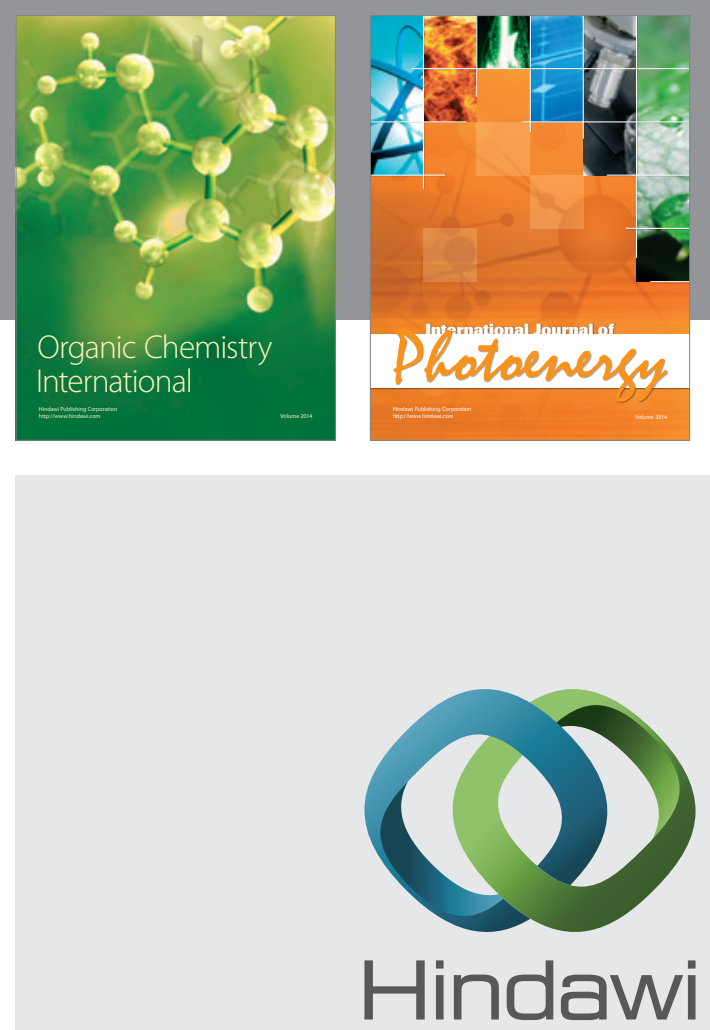

Submit your manuscripts at

http://www.hindawi.com
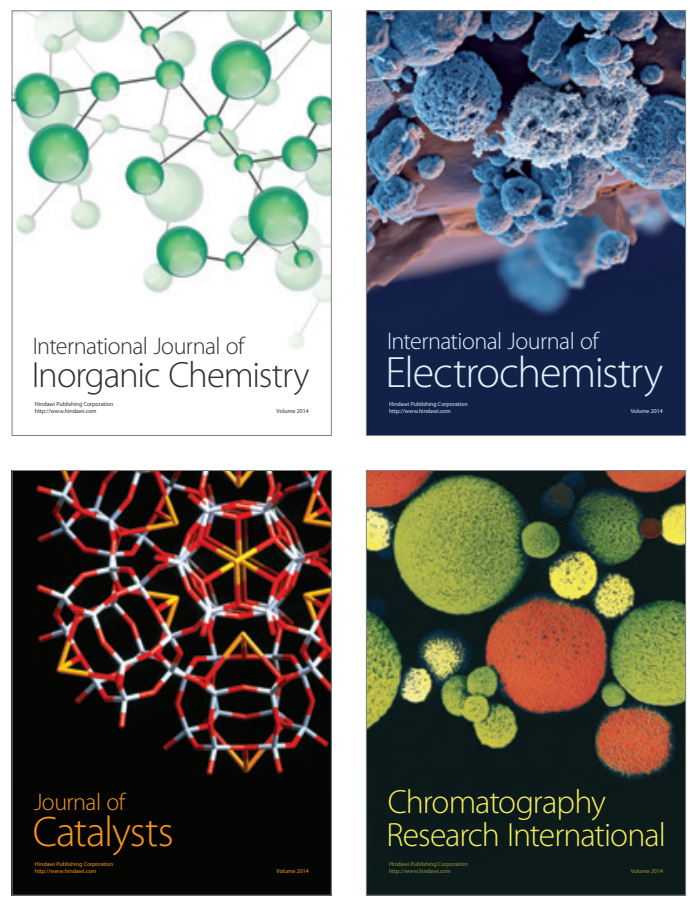
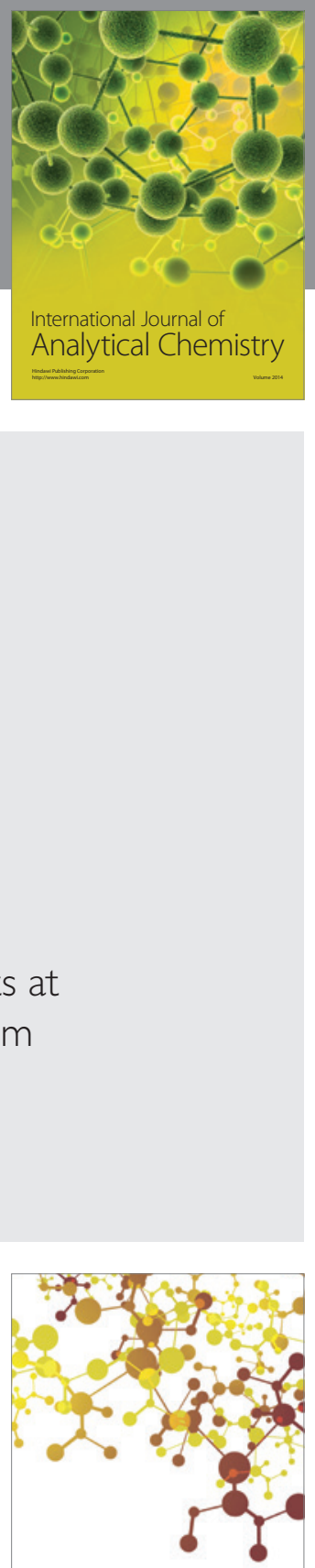

Journal of

Applied Chemistry
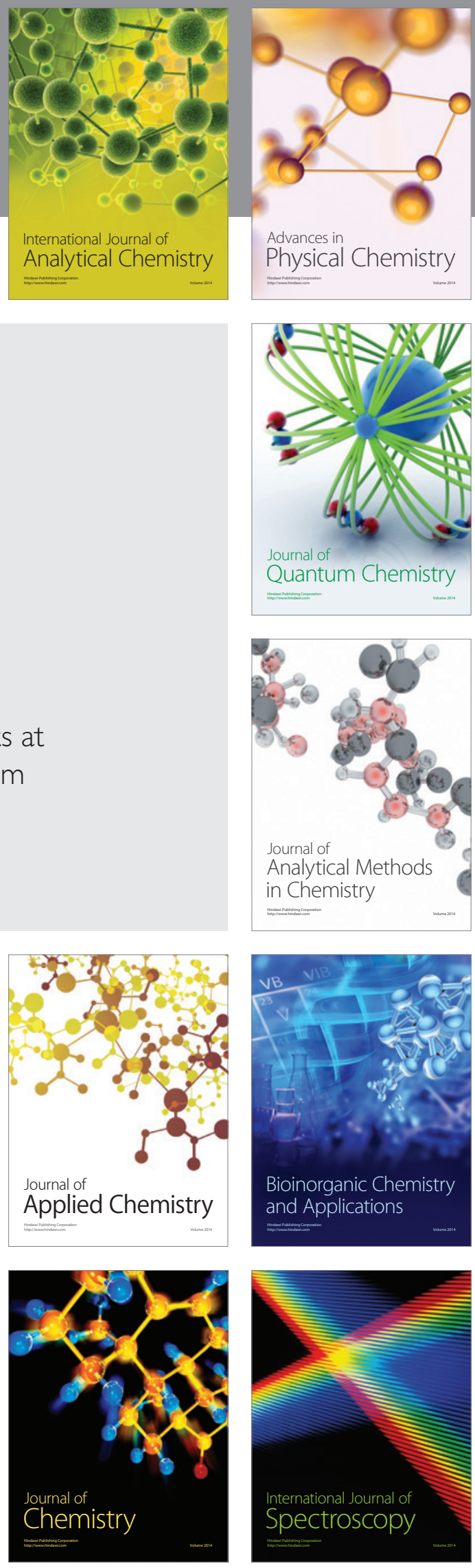